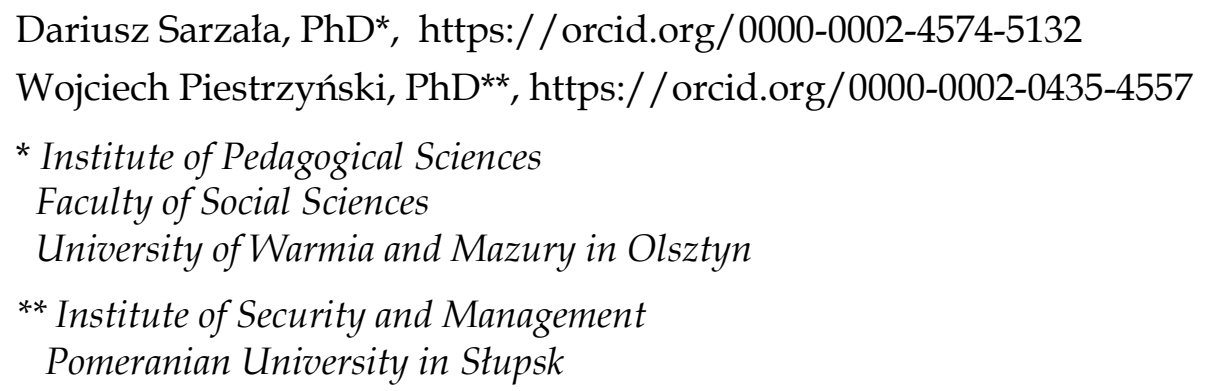

\title{
Resocialization dimension of prisoners' religiosity
} Resocjalizacyjny wymiar religijności więźniów ${ }^{1}$

\author{
https://doi.org/10.34766/fetr.v48i4.1011
}

\begin{abstract}
The article presents issues related to penitentiary social resocialization, taking into account the social rehabilitation dimension of prisoners' religiosity. Based on the results of previous research on this subject area and the literature on the subject, a thorough analysis of religiosity as a factor determining the effectiveness of social resocialization of offenders was carried out. Analyzing social resocialization as a process of internal transformation of a socially maladjusted person in the context of religious commitment, it was indicated that the process of penitentiary social rehabilitation taking into account the religious dimension of offenders may have a significant impact on changing the current anti-social behavior. Based on the analysis, it was also shown that focusing on religious life helps prisoners to change their current lives and makes it easier for them to start a new life path and protects them from returning to crime. The subject matter is an important topic from the point of view of social resocialization and moral renewal of a socially maladjusted man, which has not yet been subjected to a broader scientific analysis in the field of social sciences.
\end{abstract}

Keywords: Prisoners, resocialization, religiosity, personal security, prison chaplaincy

Abstrakt: W artykule poruszono problematykę dotyczącą resocjalizacji penitencjarnej $\mathrm{z}$ uwzględnieniem resocjalizacyjnego wymiaru religijności więźniów. $W$ oparciu o wyniki dotychczasowych badań, dotyczących tego obszaru tematycznego oraz literaturę przedmiotu, przeprowadzono wnikliwą analizę religijności jako czynnika warunkującego skuteczność resocjalizacji sprawców przestępstw. Analizując resocjalizację jako proces przemiany wewnętrznej człowieka niedostosowanego społecznie w kontekście zaangażowania religijnego wskazano, że proces resocjalizacji penitencjarnej uwzględniający wymiar religijny sprawców przestępstw może mieć istotny wpływ zmianę dotychczasowych aspołecznych zachowań. Na podstawie przeprowadzonej analizy wykazano również, że skoncentrowanie się na życiu religijnym pomaga więźniom $\mathrm{w}$ przemianie dotychczasowego życia i ułatwia im rozpoczęcie nowej drogi życiowej oraz chroni przed powrotem do przestępczości. Podjęta tematyka stanowi ważny z punktu widzenia resocjalizacji i moralnej odnowy człowieka niedostosowanego społecznie temat, który nie został jeszcze poddany szerszej analizie naukowej na gruncie nauk społecznych.

Słowa kluczowe: więźniowie, resocjalizacja, bezpieczeństwo osobiste, religijność, duszpasterstwo więzienne

\section{Introduction}

Reflecting on penitentiary social rehabilitation, which is a process of human internal transformation conditioning their pro-social functioning, the importance of

\footnotetext{
${ }^{1}$ Artykuł w języku polskim dostępny jest na stronie:

https://www.stowarzyszeniefidesetratio.pl/Presentations0/2021-4Sarza2.pdf
} 
influencing the religious involvement of people deprived of liberty is increasingly recognized. This issue has been addressed by both Polish and foreign researchers interested in this subject area (Urbanek, 2007; Sakowicz, 2009; Romanowicz, Tomczyszyn, 2015; Bębas, 2015, Stansfield, Mowen, Skowroński, Domżalska, 2017; O'Connor, at al., 2017; Morag, Teman, 2018).

While approaching to analyze this issue, it should be emphasized that both the rehabilitation effects and the development of religiosity can act as corrective measures addressed to people who lead a criminal lifestyle, who are serving a sentence of imprisonment. Authors dealing with this issue emphasize that religious commitment increases the chance for permanent rehabilitation and social readaptation.

In the further part of the study, an analysis on the social rehabilitation dimension of convicts will be carried out, based on the latest literature on the issues falling within the scope of the discussed considerations. The main research goal was aimed at indicating religiosity as a factor conditioning the process of internal transformation of a person deprived of liberty and enabling the achievement of the goals of a penitentiary social rehabilitation.

The implementation of the above research intent required an analysis of social rehabilitation as a process of internal transformation of the offenders and religiosity in relation to the rehabilitation of people living in prison isolation. Attention will also be paid to the importance of the activity of prison chaplaincy in the development of religiousness of convicts and shaping their system of values and pro-social attitudes, or a sense of a personal security in the conditions of a difficult situation, which is created by prison isolation. Pointing to the legitimacy of the interest in this topic, it should be noted that so far little research and analysis has been carried out on this issue, especially regarding a more complete presentation of the rehabilitation dimension of religious involvement of prisoners.

\section{Rehabilitation as a process of an internal transformation of the offenders}

When starting the analysis of the social rehabilitation process, it should be emphasized that in the literature on the subject, social rehabilitation is perceived as a process that is aimed at restoring developmental homeostasis to a person who is to some extent in conflict with society or with themselves and looking for the sources of the existing conflict (Kowalski, 2020, p. 35).

The analysis of reflection conducted in the field of pedagogy indicates a shift of considerations from the area of behavioral and psychodynamic orientations, which are focused on deficits and attempts to minimize or remove them, towards 
cognitive and humanistic concepts, which equate social rehabilitation with educational activity aimed at the comprehensive development of people who manifest symptoms of social maladjustment or at risk of this phenomenon (Opora 2016; Kupiec 2019). It is emphasized that the planned changes are implemented by a socially maladjusted person, in accordance with a planned pace and direction, based on their resources, with the simultaneous support of the social environment and cooperation with it (Wysocka 2015, p. 37). In the process of social rehabilitation, it is therefore important to discover resources that will allow for a "holistic reconstruction of a self" (Muskała 2016 , pp. 176-178).

Traditionally, social rehabilitation has been perceived as a pedagogical activity focused on the reorientation of attitudes, beliefs and behaviors of socially maladjusted individuals, the purpose of which is to enable them to perform adequate and socially acceptable roles. The dominant features in practical activity focused on this type of research activity are: the elimination of disturbances in behavior, the development of correct social attitudes and the channeling of uncontrolled instincts. On the other hand, the creators of the modern concepts perceive social rehabilitation in a systematic way, combining classes of activities that cover different levels of educational reality: behavioral level, satisfying needs, inclusion in the current of social life, shaping a positive way of thinking (Kowalski, 2020, p. 45).

K. Pierzchała points out that social rehabilitation means building a personal and social identity, based on "an optimistic anthropology, expressing faith in the good of human nature - often deeply dormant due to drastic educational negligence in the course of the previous stages of development" (Pierzchała, 2018, p. 79).

It should also be noted that social rehabilitation addressed to people serving the sentence of imprisonment is called in the literature of the subject a penitentiary rehabilitation. This rehabilitation is defined as "the entirety of actions intended and programmed by the pedagogical and psychological staff addressed to criminals serving a sentence of imprisonment in correctional facilities" (Machel, 2010, p. 176).

The literature on the subject emphasizes that the main goal of a penitentiary social rehabilitation is not only to convey certain knowledge and recommend new styles of behavior, but also to change characterological habits, and in particular to eliminate unfavorable and anti-social attitudes that determine the anti-social behavior of a person (Machel, 2003, p. 21).

In its main assumptions, a penitentiary social rehabilitation is focused on the elimination of anti-social attitudes that are inconsistent with the norms and principles of social order. The implementation of the process of penitentiary social rehabilitation takes place with the use of specific methods that enable to make changes in the personality of prisoners and to obtain the desired changes in behavior 
(Machel, 2003, p. 34). Therefore, penitentiary rehabilitation makes it possible for the offender to integrate with society. Rehabilitation understood in this way creates an opportunity for a conflict-free functioning in society and the implementation of constructive life goals.

The process of penitentiary social rehabilitation consists not only in conscious, but also voluntary and permanent acceptance by a given person of generally applicable social and moral standards of conduct. Researchers dealing with this issue emphasize that taking social rehabilitation impacts, changes in the structure and mechanisms of personality and motivation can be made, which protects against repeated violations of legal, moral and social norms and creates the opportunity to meet needs and achieve higher levels of development, as well as integrate the personality towards physical, mental, social and spiritual well-being (Ostrowska, 2008, p. 228). Rehabilitation, therefore, creates opportunities for discovering the authentic meaning of one's own life.

The analysis carried out so far allows for the conclusion that the purpose of penitentiary social rehabilitation is to achieve such changes in the area of personality of socially maladjusted persons serving a sentence of imprisonment, which, after leaving the prison, will allow to prevent re-undertaking of criminal behavior and facilitate proper functioning in society.

Interactions undertaken as a part of penitentiary social rehabilitation are focused on evoking in the convict understanding for social matters and a sense of the need to respect moral and legal norms. In addition, it is important to form the belief that restrictions on the subjective rights of the convicted persons, related to the stay in conditions of prison isolation, are primarily aimed at helping in the process of social rehabilitation and re-adaptation.

The effectiveness of the social rehabilitation process depends, however, on the degree of openness of the sentenced persons to this process, and therefore of their will to be different - "better". This goal can be achieved primarily as a result of motivational interactions leading to internal moral reflection. Therefore, an important task of social rehabilitation must be the formation of one's own system of values, consistent with generally accepted norms (Sarzała, 2005, pp. 181-182).

In the process of social rehabilitation, the most important factor is the conscious will to help the convict, which should be expressed in a personal decision to change the current life (Hołyst, 2017, p.16). The model of social rehabilitation interactions, adopted in Poland, therefore assumes that rehabilitation is an offer addressed to the convicted person, without any form of coercion. Acceptance of this offer by a person serving a sentence of imprisonment voluntarily is a condition for starting the process of internal transformation. On the other hand, the imposition of 
an "obligation" to rehabilitate would lead to a distortion of the idea of a conscious self-change.

However, penitentiary rehabilitation is a difficult and a long-term process, conditioned by many social, economic, psychological and biological factors. In the case of rehabilitation of the offenders, it is difficult to expect that all of them, especially those showing a high degree of demoralization and connections with the criminal world, heretofore negative to the social and legal order, will undergo a transformation and express genuine repentance and a desire to be better than before and to be full-fledged members of society.

2. Religiousness and the process of social rehabilitation and safety of persons deprived of liberty

In penitentiary social rehabilitation as a process with a complex degree of difficulty (Woźniak, 2021, pp. 414-415; Kędzierski, 2018, p. 49), aimed at the internal transformation of the offenders, one cannot ignore the importance of religiosity in changing the system of values and the related existing patterns of behavior. According to Batson and Stock (2004, p. 141), the most important function of religiosity is to provide answers to questions arising from the confrontation of human needs with life situations that a person experiences. These authors point out that religiosity has the potential to answer questions bothering people at all levels of their needs.

Researchers of this issue also emphasize that religiosity is the strongest factor influencing the attribution of meaning to human beliefs, goals and values (Park, Edmondson, Hale-Smith, 2013, p. 157). It also reflects the individual, specific and autonomous relationship of a human being as the subject to God and the supernatural.

However, Allport (1967, p. 432) divided religiosity into external and internal one. The first type of religiosity is instrumental, because it is not the main motive in life, but an instrument for obtaining one's own benefits. People presenting this type of religiosity are characterized by a lack of insight into themselves, as well as an ability to realistically perceive both themselves and other people. On the other hand, internal religiosity has an impact on the entirety of a person's life, especially motivation and their actions, and connects values with social norms. This type of religiosity is therefore more reflective and diversified, as well as personal and universal, oriented towards brotherhood, love of neighbors and kindness. In the light of the analysis, it can be concluded that religiosity is a certain socio-cultural and psychological phenomenon that affects all spheres and areas of human existence. 
The process of rehabilitation, taking into account the spiritual and religious dimension of the offenders, may therefore lead to a change in attitudes and at the same time cause a change in a current life. The convicts are not only people who are lost and in need of spiritual guidance, but also those who "..find themselves on the margins of life, often in a hopeless situation, discouraged, at odds with God, with themselves and with the whole sociocultural, moral and religious order" (Tyberski, 2007, p. 217). This problem was clearly emphasized by John Paul II, who said: “A prisoner, every prisoner who serves a sentence for a committed crime, has not ceased to be a human being, although burdened with weakness, threat and sin - maybe a crime - and even stubborn relapses towards them, but not deprived of the wonderful possibility of improvement, of returning to oneself, which is a conversion of a human being, the renewal of the image of God. You are condemned, it is true, but not damned" (John Paul II, 1991).

Moreover, the involvement of prisoners in religious life has a significant psychological dimension, as it favors reflection on one's own deeds and makes it possible to come to terms with the sentence, "giving at the same time a sense of relief that there is Someone (God) who forgives and does not condemn" (Wdowiszewski, 2016, p. 346). At the same time, it directs to a new way of life, creating a new perspective of the future, facilitates coping with the feeling of loss of freedom, which in the case of the imprisoned people's age can be a very difficult experience, especially when it happens for the first time.

When analyzing the issues raised, it should also be noted that serving life imprisonment in conditions of prison isolation can be perceived as an example of a difficult life situation. Prison, as a place of stay characterized by forced isolation, is a special type of an institution that creates a specific social environment that is significantly different from the normal conditions of human functioning. First of all, it should be noted that the spatially closed environment has many features characteristic of total institutions (Goffman, 1975, pp. 3-4). The specificity of total institutions consists primarily in the fact that, due to their isolationism, they make it impossible to meet many basic human needs, including the need for security (Ostrowska, 2008, p. 256). Staying in prison is not only a significant inconvenience in the form of deprivation of liberty, but it also hinders the possibility of making decisions about one's own life activity and limits ties with the current social environment (family, work, friends, etc.). It is a difficult and complex situation, because apart from their freedom being restricted, a given person is not only in a new social situation, but also in an unfamiliar environment functioning on completely different principles (Romanowicz, Tomczyszyn, 2015, p. 94). Prison isolation also makes it necessary to be around people who have been imposed by the 
prison administration. As a consequence, such a situation forces people to live with those from different backgrounds, with different motives of behavior, a deepened degree of demoralization, with a disturbed personality, violating commonly accepted norms and not following the patterns of social behavior.

Therefore, rehabilitation in conditions of prison isolation encounters serious barriers and is often disturbed as a result of the functioning of the phenomena and mechanisms contrary to the assumed goals of penitentiary interactions. Moreover, staying in prison creates in many cases a difficult situation and may cause severe stress and deprivation of many needs (Machel 2006; 2005; Sarzała 2013, 2016; Piotrowski, Ciosek, 2016). Imprisoned people perceive their previous life differently than before, not always in a positive perspective. Many of the things they were striving for lose any importance in prison. The result of being in prison isolation may not only be a high level of depression and a sense of hopelessness, but also a fear of how their future will unfold, also after walking free (Fidelus 2019, p. 134).

In the case of people living in prison isolation, a significant role may be played by religious commitment conditioning such mental states as: joy, hope, compassion or forgiveness. As emphasized by M. Ryś (2009, p. 259), mature faith favors the acceptance of difficult situations without a sense of failure and gives strength in search of the solutions aiming at taking necessary actions, and the hope that comes from faith strengthens the belief in the legitimacy of taking trouble and adopting the attitude of trust. On the other hand, Park, Edmondson and Hale-Smith (2013, p. 157) claim that religiosity helps to accept and acknowledge the meaning of events, even in the situation of not understanding their essence and importance.

The results of the research on this issue indicate that people serving prison sentences characterized by an active, religiously focused life show a significantly lower rate of anxiety, anger and depression than people with a moderate intensity of spiritual life, not religiously concentrated (Skowroński, Domżalska, 2017, p. 106)

It is also worth emphasizing that, in accordance with Pargament's (1997) concept of religious coping with stress, religiosity provides ways to understand and deal with suffering and loss, and makes difficult realities more understandable and bearable for a human being. A religiously committed person has greater opportunities to increase the sense of control over a difficult situation, as well as a sense of security and the ability to eliminate ambiguities that appear in everyday life.

The development of religiosity in conditions of prison isolation is especially influenced by pastoral work, which, as shown by research results, affects the thinking of convicts, their emotional reactions and cognitive elements (Nowacki, 2012, p. 181). It should be emphasized that, while fulfilling the evangelization mission, the church provides its pastoral care to various environments and social 
groups, as well as to people in conditions of prison isolation. Therefore, a type of religious ministry adequate for this purpose was created, called prison pastoral care. In the sphere of prison chaplaincy, in Polish penitentiary institutions, in addition to the sacramental service, there are also individual conversations between chaplains and lay volunteers with convicts, as well as contacts with their families, various forms of cultural, didactic and therapeutic activities. The chaplain in prison reality is not only a chaplain, but also an educator, a therapist, a role model and an animator of cultural and sports life. Therefore, pastoral interactions with people in prison isolation focus on the conscious formation of a religious attitude (Pol, 2017, p. 115), which, in turn, enables the formation of a proper personal and social attitude. Prison ministry has therefore set itself an important rehabilitation task, which is, through the development of religiosity, restoring a person deprived of liberty to society, but in different forms and referring to a different sphere of consciousness than in the case of classic social rehabilitation interactions.

\section{Summary}

The conducted analysis shows that religious commitment plays a vital role in the process of rehabilitation of offenders and restoration of a person deprived of liberty to society. The development of religiosity is not only conducive to understanding, accepting and coping with a difficult situation, such as prison isolation, but it also allows you to adapt new values and make a spiritual transformation that enables you to start a new, crime-free stage of life.

A positive aspect of religiosity in the process of penitentiary social rehabilitation is also the fact that religion can help to make a retrospection and understand the obligation and sense of serving a sentence, it can also help not to succumb to negative prison customs and sensitize to the need to compensate crime victims or their relatives.

An important element of restoring prisoners to society is therefore a pastoral work, carried out in penitentiary institutions, which is an important factor of rehabilitation taking into account the spiritual and religious dimension of convicts, influencing a change in their lives and taking responsibility for them. As a result of the pastoral work that enables prisoners its implementation, it becomes possible to develop and deepen religiosity, and systematic contact with a clergyman and support on his part strengthens the convict's system of values that play a key role in the social functioning of every human being.

Therefore, pastoral work focused on religious education helps to increase the effectiveness of social rehabilitation and the feeling of personal security in prison 
isolation. When perceiving religious commitment in the context of social rehabilitation, it should be noted that it has a significant value as a factor in changing human social functioning.

To sum up, it is worth mentioning that the conclusions from the analysis may be helpful in setting goals for further empirical research, the conduct of which is necessary to show the social rehabilitation dimension of religiosity more fully than before, since it is a factor conditioning the internal transformation of a person unable to function without conflicts in society.

\section{Bibliography:}

Allport, G.W. (1967). Personal Religious Orientation and Prejudice, Journal of Personality and Social Psychology, 5, 432-443.

Batson, C.D., Stocks, E.L. (2004). Religion: its core psychological functions, (in:) J. Greenberg, S.L. Koole, T. Pyszczynski (eds.), Handbook of experimental existential psychology,141-155, New York: Guilford Press.

Bębas, S. (2015). Rola religii w procesie resocjalizacji, Toruń: Wydawnictwo Edukacyjne Akapit.

Fidelus, A. (2019). Pomoc społeczna opuszczających więzienia - propozycje rozwiązań systemowych w zakresie wsparcia skazanych, Roczniki Pedagogiczne, 11(47), 131-145, doi: https://doi.org/10.18290/rped.2019.11s-8.

Goffman, E. (1975). Charakterystyka instytucji totalnych, (w:) W. Deczyński, A JasińskaKania, J Szacki (eds.), Elementy teorii socjologicznych. Materiały do dziejów wspótczesnej socjologii zachodniej, 150-151, Warszawa: PWN.

Hołyst B., 2017, Kryminologiczna ocena granic resocjalizacji, (in:) T. Sołtysiak, M. Gołembowska (eds.), Resocjalizować we współczesnej rzeczywistości społecznej? Ale jak?, 16-24, Bydgoszcz: Wydawnictwo UKW.

Jan Paweł II (1991). Przemówienie w Zakładzie Karnym w Płocku, IV Pielgrzymka Jana Pawła II do Polski: 1-9.06 i 13-16.08.1991,

http://www.opoka.org.pl/biblioteka/W/WP/jan_pawel_ii/przemowienia/30plock _07061991.html.

Kędzierski, W. (2018). Możliwości poprawy efektywności oddziaływań w kierunku readaptacji społecznej w warunkach izolacji penitencjarnej, Resocjalizacja Polska, 16, 49-64, doi: https:/ / doi.org/10.22432/pjsr.2018.16.05

Kowalski, M., Ernest, M. (2020). Strategie myślenia o resocjalizacji na tle przemian paradygmatów w pedagogice, Resocjalizacja Polska, 19, 35-48, doi:

https:// doi.org/10.22432/pjsr.2020.19.03

Kupiec, H. (2019). Tożsamość nieletnich a motywacja do zmiany w warunkach placówki resocjalizacyjnej, Kraków: Oficyna Wydawnicza „Impuls”.

Machel, H. (2003). Więzienie jako instytucja karna i resocjalizacyjna, Gdańsk: Arche. 
Machel, H. (2010). Resocjalizacja penitencjarna: istota, dylematy terminologiczne, społeczny sens, kilka uwag teoretycznych i kadrowych, Resocjalizacja Polska, 1, 174-192.

Morag, M., Teman, E. (2018). The "Watchful Eye of God": The Role of Religion in the Rehabilitation and Reentry of Repentant Jewish Prisoners, International Journal of Offender Therapy and Comparative Criminology, 62(7), 2103-2126, doi: https:// doi.org/10.1177/0306624X17698054

Muskała, M. (2016). „Odstapienie od przestępczości” w teorii i praktyce resocjalizacyjnej, Poznań: Wydawnictwo UAM.

Nowacki, Z. (2012). Wielowymiarowe znaczenie pracy duszpasterskiej w stosunku do osób pozbawionych wolności, Przegląd Więziennictwa Polskiego, 76-77, 155-183.

Opora, R. (2016). Ewolucja niedostosowania społecznego jako rezultat zmian w zakresie odporności psychicznej i znieksztatceń poznawczych, Gdańsk: Wydawnictwo UG.

Ostrowska, K. (2008). Psychologia resocjalizacyjna. W kierunku nowej specjalności psychologii, Warszawa: Wydawnictwo Fraszka Edukacyjna.

Pargament, K. I. (1997). The psychology of religion and coping, New York, NY: New.

Park, C.L., Edmondson, D., Hale-Smith, A. (2013). Why religion? Meaning as motivation, (in:) K. I. Pargament, J. J. Exline, J. W. Jones (eds.), APA handbook of psychology, religion, and spirituality (Vol 1): Context, theory, and research, 157-171, Washington, DC, US: American Psychological Association.

Pierzchała K. (2018) Aksjologiczne konteksty resocjalizacji osadzonych w aspekcie założeń personalizmu chrześcijańskiego, Resocjalizacja Polska, 18, 69-90, doi: https:// doi.org/10.22432/pjsr.2018.16.02

Piotrowski, J.M. Ciosek, M. (2016). Izolacja więzienna jako złożona sytuacja trudna, (in:) M. Ciosek, B. Pastwa-Wojciechowska (eds.), Psychologia Penitencjarna, 428-460, Warszawa: Wydawnictwo Naukowe PWN SA.

Pol, D. (2017). Duszpasterstwo więzienne w Polsce w perspektywie 25 lat doświadczeń pastoralno-resocjalizacyjnych, Przegląd Więziennictwa Polskiego, 96, 103-128.

Romanowicz, W., Tomczyszyn, D. (2015). Stosunek do religii osób odbywających karę pozbawienia wolności a miejsce religii we współczesnym świecie, Rozprawy Społeczne, 9 (3), 93-100.

Ryś, M. (2009). Rola fides et ratio w sytuacjach trudnych, (in:) J. Krokos, M. Ryś (eds.), Czy rozum jest w konflikcie z wiarą?, 249-260, Warszawa: Wydawnictwo Jana Pawła II.

Sakowicz, T. (2009). Wybrane aspekty środowiska rodzinnego w percepcji i ocenie osób osadzonych w polskich zakładach karnych, Kraków: Oficyna Wydawnicza „Impuls”.

Sarzała D. (2016). Rodzina osoby przebywającej w izolacji więziennej jako środowisko wsparcia społecznego, Kwartalnik Naukowy Fides et Ratio, 24, 278-293. 
Sarzała, D. (2005). Rola wartości w resocjalizacji młodocianych sprawców przestępstw, (in:) W. Woźniak (eds.), Przestępca i skazany nie traca godności osoby, 167-182, Olecko: Wydawnictwo Wszechnicy Mazurskiej-Acta Universitatis Masuriensis.

Sarzała, D. (2013). Patologiczne zachowania więźniów w kontekście izolacji i resocjalizacji penitencjarnej, Warszawa: Oficyna Wydawnicza Aspra JR.

Skowroński, B., Domżalska, A. (2017). Duchowość osób odbywających karę pozbawienia wolności, Resocjalizacja Polska, 13, 87-108, doi: https:// doi.org/10.22432/pjsr.2017.13.07

Stansfield, R., Mowen, T.J., O'Connor, T., at al.( 2017). The Role of Religious Support in Reentry: Evidence from the SVORI Data, Journal of Research in Crime and Delinquency, 54 (1), 111-145, doi: https:/ / doi.org/10.1177/0022427816657578

Tyberski, K. (2007). Posługa duszpasterska w zakładzie karnym w Iławie oraz jej formy, (in:) J. Świtka, M. Kuć (eds.), Duszpasterstwo więzienne w pracy penitencjarnej, 217-226, Lublin: TN KUL.

Urbanek, A. (2007). Miejsce aktywności religijnej więźniów w teleologii pedagogiki resocjalizacyjnej: na podstawie badań prowadzonych w wybranych zakładach karnych, Zeszyty Naukowe Państwowej Wyższej Szkoty Zawodowej im. Witelona w Legnicy, 2, 173-185.

Wdowiszewski A. (2016). Duszpasterstwo więzienne, (in:) M. Ciosek, B. PastwaWojciechowska (eds.), Psychologia Penitencjarna, 327-351, Warszawa: Wydawnictwo Naukowe PWN SA.

Woźniak, W. (2021). Development of biophilic character as a factorin effective resocialization, Kwartalnik Naukowy Fides et Ratio, 3 (47), 414-423, doi: https:// doi.org/10.34766/fetr.v47i3.906

Wysocka, E. (2015). Diagnoza pozytywna w resocjalizacji. Model teoretyczny i metodologiczny, Katowice: Wydawnictwo UŚ. 